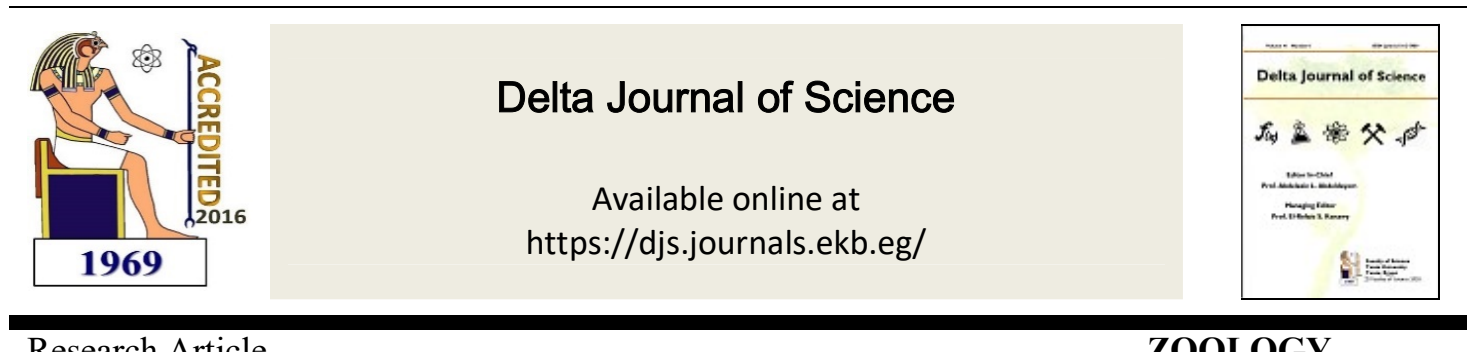

Research Article

ZOOLOGY

\title{
Age-related biochemical and histological changes in the soleus muscle of male mice
}

\author{
Amira R. Hammad ${ }^{a}$, khairat B. El-Baradie ${ }^{b}$, Samaa M. Bakr ${ }^{\mathrm{a}}$, Abeer A. Alm-Eldeen ${ }^{\mathrm{b}}$
}

a Zoology Department, Faculty of Science, Kafrelsheikh University, Egypt

${ }^{b}$ Zoology Department, Faculty of Science, Tanta University, Egypt

KEY WORDS

Aging, Antioxidants, Skeletal muscle.
ABSTRACT

During aging, skeletal muscle is subjected to progressive loss of muscle mass and strength (sarcopenia) and a decline in the functional ability. The reduction in the antioxidative capacity of the skeletal muscle resulting in an abnormal accumulation of the reactive oxygen species (ROS) that is one of the possible causes of the decline in muscle performance. In this study the histological changes in the soleus muscles of male mice at the age of $1^{\text {st }}$ and $15^{\text {th }}$ old were examined and the activities of the antioxidant enzymes, CAT and SOD, non- enzymatic antioxidant GPH and MDA level were measured to clarify the age-related changes in healthy subjects. Results showed that there is a significant reduction $(\mathrm{P} \leq 0.05)$ in the antioxidants SOD, CAT and GPH and there is a significant increase $(\mathrm{P} \leq 0.05)$ in MDA level at the age of $15^{\text {th }}$ month when compared to $1^{\text {st }}$ month old. We concluded that the activities of the antioxidants were affected by aging. Moreover, there is age- related lipid peroxidation.

\section{Introduction}

Aging is characterized by a decrease in the physical function of the daily activities resulting in reduced quality of life. The decrease of motor activity is related to the weakness and the atrophy of the muscle (Miljkovic et al., 2015). Sarcopenia is one of the main characteristics of aging and, is characterized by loss of skeletal muscle mass and strength (Edstrom et al., 2007; Frontera and Ochala, 2015; Musumeci et al., 2015). The decline of the muscle strength was due to the progressive increase in the catabolism with a decrease in the anabolism, as well as the reduced regeneration capacity of the muscle (Musumeci et al., 2015). The muscle reduced in size progressively, and muscle fibers were replaced by fat and fibrous tissue. This causes an increase in the oxidative stress, changes in the muscle metabolism, and degeneration of the 
neuromuscular junction, resulting in progressive loss of muscle function and frailty (Tsochatzis et al., 2014). Sarcopenia increased by $14 \%$ in people those aged between 65 and 70 years and $53 \%$ after 80 years (Santilli et al., 2014).

The skeletal muscle constitutes of $40 \%$ of the body weight and contains $50 \%-75 \%$ of the body's proteins. The principal functions of the skeletal muscle are maintaining body structure and posture, controlling motor movement and storing energy (Fong and Tapscott, 2013). Skeletal muscle is considered as an organ for the muscular system which consists of the tissues of skeletal muscle, connective, nerve and blood or vascular to serve multitude of functions. The good maintenance of skeletal muscle health is important for the prevention of various diseases and the psychological stress due to the disability (Bentzinger et al., 2012). Skeletal muscle is made up of thousands of cylindrical, multinucleated muscle fibers (myofibers) composing an array of stacked myofibrils running the entire length of the cell. Myofibrils consist of thick and thin filaments which are organized into a contractile unit called a sarcomere and surrounded by a basal lamina (Scime et al., 2009). Adult skeletal muscle undergoes changes in its size and metabolic activity in response to extracellular and intracellular effects (Sandri, 2008).

Oxidative stress is characterized by increased levels of reactive oxygen species (ROS) and/or reactive nitrogen species (RNS). Oxidative stress can be caused by decreased antioxidant capacity due to low concentrations of the antioxidants and reduced antioxidant enzymes activity, and/or by increased ROS production (Altenhofer et al., 2015). Skeletal muscles consume large quantities of oxygen and can generate a great amount of ROS and (RNS) (Choi et al., 2016). The antioxidant system includes endogenous and exogenous molecules neutralizes the oxidative stress. The main antioxidant enzymes are superoxide dismutase, catalase, and glutathione peroxidase (Bouzid et al., 2015). These enzymes can be altered by exercise, nutrition, and aging (Franzke et al., 2015). The antioxidants maintain the muscle redox status and decrease ROSinduced intracellular changes (Baumann et al., 2016). Due to the increased oxidative stress levels observed in aged muscle, ROS accumulation has been suggested as playing a role in muscle changes and sarcopenia. Harman (1956) was the first to propose the free-radical theory of aging. Therefore, the present study will examine the biochemical and histological changes that may appear in aged male mice that had 15 month old.

\section{Materials and Methods}

\section{Animals}

Twenty-eight male mice of 1 and 15 months old were used in the present study. The mice were housed in steel mesh cages in the research lab at the Faculty of Science, Kafrelsheikh University, Kafrelsheikh, Egypt. They were maintained under standard conditions of temperature, humidity, and $12 \mathrm{~h}$ light/dark cycle and were provided with standard diet and excess tap water. The procedures of the experiment adhered to the guidelines of the ethical committee of Kafrelsheikh University, Kafrelsheikh, Egypt.

\section{Skeletal muscle sampling:}

Soleus muscles of mice were collected from the mice in each group under strict hygienic conditions to minimize the contamination or autolysis of the samples. Then, some samples were quickly preserved in $10 \%$ neutral buffered formalin solution for 12 hours for histological study and the other samples were frozen in liquid nitrogen before storing at $-80 \quad{ }^{\circ} \mathrm{C}$ to be used for biochemical analysis.

\section{Biochemical investigations:}


Catalase activity was estimated according to the method of $\mathbf{X u}$ et al. (1997). SOD was estimated according to the method of Kakkar et al. (1984). Glutathione level in cell lysates was estimated by the method of Ellman (1959). Lipid peroxidation was estimated colorimetrically by measuring thiobarbituric acid reactive substances (TBARS). The method is based on the determination of malondialdehyde (MDA) an end product of lipid peroxidation, which can react with thiobarbituric acid to yield a pink colored complex exhibiting a maximum absorption at 532nm (Yoshioka et al., 1979).

\section{Histological investigations:}

The preserved soleus muscles in $10 \%$ formalin were washed with running water overnight then samples were dehydrated by passing through a graded series of ethanol and then were embedded in paraffin. Sections of $5 \mu \mathrm{m}$ were cut, deparaffinized, hydrated and were stained with hematoxylin and eosin. The samples were processed for examination under light microscope and were photographed under standard procedures (Bancroft et al., 1994).

\section{Statistics}

All data are the means of 4 replicates. One-way analysis of variance (ANOVA), was used. If there a significant difference between means, Tukey post hoc comparisons were performed. For all statistical tests $\mathrm{P}$ values $\leq 0.05$ was considered to be statistically significant. Means that do not share a letter are significantly different.

\section{Results}

\section{Biochemical assay:}

Results showed a significant reduction $(\mathrm{p} \leq 0.05)$ in the activity of the SOD, CAT, and GPH in male mice at the $15^{\text {th }}$ month when compared with the control group at the $1^{\text {st }}$ month. The value of SOD enzyme activity was $31.5625 \mathrm{U} / \mathrm{g}$ and $10.175 \mathrm{U} / \mathrm{g}$ at the $1^{\text {st }}$ month the $15^{\text {th }}$ month, respectively. The value of CAT enzyme activity was $88.35 \mathrm{U} / \mathrm{g}$ and $46.375 \mathrm{U} / \mathrm{g}$ at the $1^{\text {st }}$ month the $15^{\text {th }}$ month, respectively. The GSH concentration was $888.0 \mathrm{mg} / \mathrm{g}$ tissue at the $1^{\text {st }}$ month and $114.7 \mathrm{mg} / \mathrm{g}$ tissue at the $15^{\text {th }}$ month. However, a significant increase $(p \leq 0.05)$ in the MDA content in mice at the age of $15^{\text {th }}$ month were recorded when compared with the control group at the $1^{\text {st }}$ month. The MDA concentration was $66.925 \mathrm{n}$ $\mathrm{mol} / \mathrm{g}$ tissue at the $1^{\text {st }}$ month and the concentration was $285.75 \mathrm{n} \mathrm{mol} / \mathrm{g}$ tissue at the $15^{\text {th }}$ month (Table 1 ).

Table 1. The effect of aging on the SOD, CAT and GPH activities and MDA level, $n=4$, Means that do not share a letter are significantly different $(p \leq 0.05)$.

\begin{tabular}{|c|c|c|c|c|}
\hline Age & $\begin{array}{l}\text { SOD } \\
(\mathrm{U} / \mathrm{g})\end{array}$ & $\begin{array}{l}\text { CAT } \\
(\mathrm{U} / \mathrm{g})\end{array}$ & $\begin{array}{l}\text { GPH } \\
(\mathrm{mg} / \mathrm{g})\end{array}$ & $\begin{array}{l}\text { MDA } \\
(\mathrm{nmol} / \mathrm{g})\end{array}$ \\
\hline $\begin{array}{l}1 \\
\text { month }\end{array}$ & $\begin{array}{l}31.5 \\
625 \pm \\
2.52^{\mathrm{a}}\end{array}$ & $\begin{array}{l}88.35 \\
\pm 2.69^{\mathrm{a}}\end{array}$ & $\begin{array}{l}888.0 \pm \\
129.05^{\mathrm{a}}\end{array}$ & $\begin{array}{l}66.93 \quad \pm \\
4.70^{\mathrm{e}}\end{array}$ \\
\hline $\begin{array}{l}15 \\
\text { months }\end{array}$ & $\begin{array}{l}10.1 \\
75 \pm \\
2.04^{\mathrm{d}}\end{array}$ & $\begin{array}{l}46.38 \\
\pm 2.66^{\mathrm{e}}\end{array}$ & $\begin{array}{l}114.7 \pm \\
50.60^{d}\end{array}$ & $\begin{array}{l}285.75 \pm \\
17.84^{\mathrm{a}}\end{array}$ \\
\hline
\end{tabular}

\section{Histological observation:}

Observation of the soleus muscles of the mice that had 1- month age showed normal architecture of the muscle fibers with bundles of nonbranching cylindrical shaped myofibers, acidophilic sarcoplasm and multiple elongated nuclei that stained dark purple and peripherally located beneath the sarcolemma. The muscle fibers of 15-month old were degenerated. 
Dark nuclei, linear nuclei, clumping of nuclei, myolysis and spacing, uncontinous sarcoplasm and wavy sarcoplasm were observed (Figure 1).
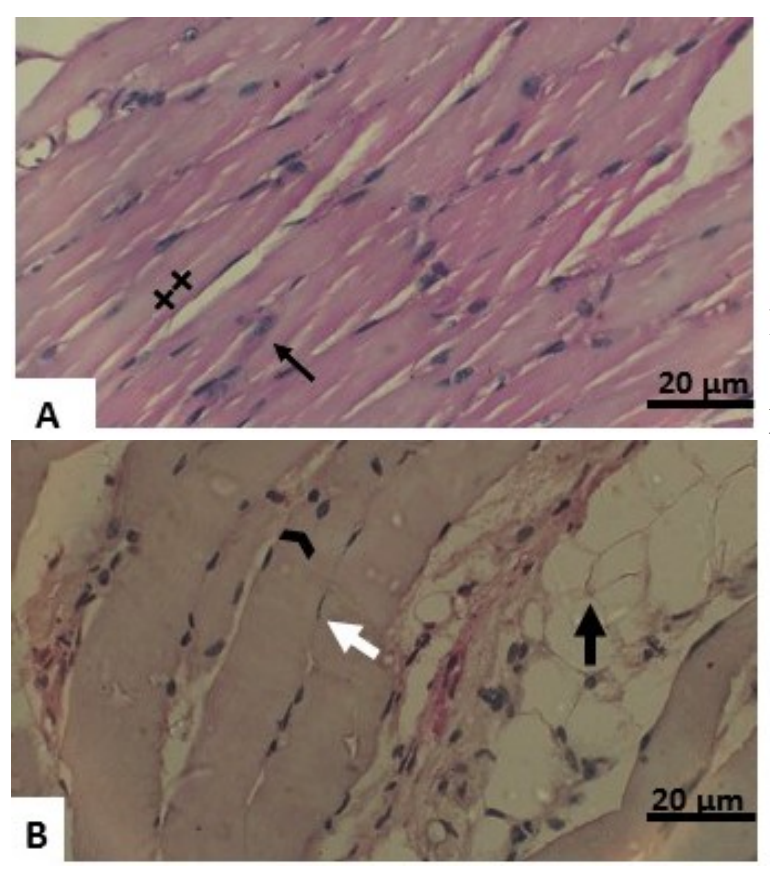

Fig. (1): Light photomicrograph of L.S of soleus muscle of the male mice stained with hematoxylin and eosin stain. (A): $1^{\text {st }}$ month age (control group), showing bundles of cylindrical shaped myofibers with acidophilic sarcoplasm $(++)$ and multiple elongated nuclei stained dark purple and peripherally located beneath the sarcolemma (black arrow). (B): $15^{\text {th }}$ month age, showing dark nucleus (black arrow head), linear nuclei (white arrow) and vacuolation (black arrow).

\section{Discussion and conclusion}

The present study was designed to investigate the age related biochemical and histological changes occurring in the skeletal muscles of the male mice. The current results showed a significant decrease in the activities of GSH, SOD and CAT, and a significant increase in MDA level with aging. The present data agreed with Gil et al. (2006) since they found that plasma MDA levels increased with age. Also, Suresh et al. (2010) and Karolkiewicz (2011) showed a decrease in the antioxidant enzymes activity such as superoxide dismutase (SOD), catalase (CAT) and glutathione peroxidase (GSH$\mathrm{Px}$ ), and the accumulation of reactive oxygen species with age.

Moreover, Inal et al. (2001) observed that SOD activities were decreased with aging in erythrocytes. They suggested that the decrease in SOD activity was related to its product, hydrogen peroxide, because exposure of intact erythrocytes to increased hydrogen peroxide caused the inactivation of endogenous SOD activity in the concentration-dependent manner Salo et al. (1988) suggested another explanation for the decrease in SOD activity since SOD includes copper and zinc. they suggested that the deficiency of zinc and copper led to a decrease in SOD activity. They also showed that MDA levels were increased with aging because of the increase of the oxidative damage.

Furthermore, the results of the current study showed differences from that of Inal et al. (2001) since they observed that CAT activities were increased. They suggested that the increase was because of the increase in Hydrogen peroxide $\left(\mathrm{H}_{2} \mathrm{O}_{2}\right)$ formation since $\mathrm{H}_{2} \mathrm{O}_{2}$ is removed by catalase (Alejendro et al., 1997). Aging is a progressive accumulation of morphological and physiological changes and is responsible for an increasing susceptibility to disease (Matsubara and Machado, 1991).

Aging is associated with increased oxidative stress and many studies displayed the age-related increase of lipid peroxidation, protein oxidative modification, and DNA damage (Gianni et al., 2004 and Gunduz et al., 2004). Skeletal muscles display a significant agerelated increase in oxidative damage. So, aged skeletal muscles were susceptible to oxidative damage to DNA, lipids, and proteins (Nabben et al., 2011). In skeletal 
muscle, increased exposure of mitochondrial reactive oxygen species (ROS) with aging reflects basic changes in redox signaling (Muller et al., 2007).

Similarly, the results of the current study suggested that the soleus muscles from aged mice (15- month old) had greater oxidative stress than muscles from the control mice of one-month age. Since our data displayed that MDA - an indicator of lipid peroxidation- increased with aging. In addition, the decreased activities of the antioxidant enzymes e.g. SOD and CAT, and the non-enzymatic GSH indicated the excessive production of free radical and reactive oxygen species which increase with aging. Current data agreed with the study of Akila et al. (2007) since they showed that lipid peroxidation was increased and antioxidants were decreased in normal elderly people.

Our results agreed with (Sheard et al., 2012) since they studied the agerelated decline in muscle fiber number in the mouse and found that leg muscles showed significant fiber loss. Moreover, Sakakima et al. (2004) showed that body mass, muscle wet weight and the fiber size were decreased with aging. Lexell (1995) displayed that the Limb muscles from older men and women are $25-35 \%$ smaller and have more fat and connective tissue than limb muscles from younger individuals. Reinking (1996) showed that the recovery of muscle mass and force following muscular injury decreased with age. Kragstrup et al. (2011) showed that the skeletal muscles display structural and biochemical changes with aging. These changes in skeletal muscle contribute to the increased stiffness and impairment in force generated by the contracting muscle fibers seen with aging due to muscle mass loss.

In conclusion, our findings have displayed that the skeletal muscle histology and the activities of antioxidants are affected by aging. Moreover, there is age- related lipid peroxidation. Therefore, free radical mediated peroxidative injury may have a critical role in the pathophysiological changes of aging.

\section{References}

Akila, V. P., Harishchandra, H., D'souza, V. and D'souza, B. (2007). Age related changes in lipid peroxidation and antioxidants in elderly people. Indian Journal of Clinical Biochemistry, 22 (1): 131-134.

Alejendro, D. B., Martha, S. B. and Nestor, O. B. (1997). Superoxide dismutase, catalase and glutathione peroxidase activities in human blood: influence of sex, age, and cigarette smoking. Clin Biochem., 30:449-54.

Altenhofer, S., Radermacher, K. A., Kleikers, P. W, Wingler, K., Schmidt, H. H. (2015). Evolution of NADPH oxidase inhibitors: selectivity and mechanisms for target engagement. Antioxid Redox Signal.; 23: 406-27.

Bancroft, J. D., Cook, H. and Turner, D. (1994). Manual of histological techniques and their diagnostic applications, 2edution. Churchill Livingstone. 457 pages

Baumann, C. W., Kwak, D., Liu, H. and Thompson, L. V. (2016). Age-induced oxidative stress: How does it influence skeletal muscle quantity and quality? J Appl Physiol., 121: 1047-52.

Bentzinger, C. F., Wang, Y. X. and Rudnicki, M. A. (2012). Building muscle: molecular regulation of myogenesis. $\underline{\text { Cold }}$ Spring Harb Perspect Biol., 4(2).

Bouzid, M. A., Filaire, E., McCall, A. and Fabre, C. (2015). Radical oxygen species, 
exercise and aging: an update. Sports Med., 45: 1245-61.

Choi, M. H., Ow, J. R., Yang, N. D. and Taneja, R. (2016). Oxidative stressmediated skeletal muscle degeneration: molecules, mechanisms, and therapies. Oxid Med Cell Longev. 2016: 6842568.

Edstrom, E., Altun, M., Bergman, E., Johnson, H., Kullberg, S., Ramirez-Leon, V. and Ulfhake, B. (2007). Factors contributing to neuromuscular impairment and sarcopenia during aging. Physiol Behav., 92(1-2):129-135.

Ellman, G. L. (1959): Tissue sulfhydryl groups. Arch Biochem Biophys., 82(1):70-77.

Fong, A. P. and Tapscott, S. J. (2013). Skeletal muscle programming and re-programming. Curr Opin Genet Dev., 23: $568-573$.

Franzke, B., Halper, B., Hofmann, M., Oesen, S., Jandrasits, W., Baierl, A., Tosevska, A., Strasser, E. M., Wessner, B. and Wagner, K. H. (2015). Group Vienna Active Ageing Study. The impact of six months strength training, nutritional supplementation or cognitive training on DNA damage in institution aliased elderly. Mutagenesis., 30: 147-53.

Frontera, W. R. and Ochala, J. (2015).

Skeletal muscle: A brief review of structure and function. Calcif. Tissue Int., 96: 183-195.

Gianni, P., Jan, K. J., Douglas, M. J., Stuart, P. M. and Tarnopolsky, M. A. (2004). Oxidative stress and the mitochondrial theory of aging in human skeletal muscle. Exp Gerontol, 39:13911400 .
Gil, L., Siems, W., Mazurek, B., Gross, J., Schroeder, P., Voss, P. and Grune, T. (2006). Age-associated analysis of oxidative stress parameters in human plasma and erythrocytes. Free Radic. Res.,40: 495-505.

Gunduz, F., Senturk, U. K., Kuru, O., Aktekin, B. and Aktekin, M. R. (2004).

The effect of one year's swimming exercise on oxidant stress and antioxidant capacity in aged rats. Physiol Res., 53:171-176.

Harman, D. (1956). Aging: a theory based on free radical and radiation chemistry. $\mathrm{J}$ Gerontol., 11: 298-300.

Inal, M. E., Kanbak, G. and Sunal, E. (2001). Antioxidant enzyme activities and malondialdehyde levels related to aging. Clin Chim Acta., 305:75-80.

Kakkar, P., Das, B. and Viswanathan, P. N. (1984). A modified spectrophotometric assay of superoxide dismutase. Indian J Biochem Biophys., 21(2):130-2.

Karolkiewicz, J. (2011). Effects of oxidative stress and free-radical mediated damage on cell structure and function connection to aging process. Ge-rontol. Pol., 19 (2): 59-67.

Kragstrup, T. W., Kjaer, M., Mackey, A. L. (2011). Structural, biochemical, cellular, and functional changes in skeletal muscle extracellular matrix with aging. Scand J Med Sci Sports, 21: 749 757.

Lexell, J. (1995). Human Aging, Muscle Mass, and Fiber Type Composition. The Journals of Gerontology Series A., 50: 1116.

Matsubara, L. and Machado, P. E. (1991). Age-related changes of glutathione 
content, glutathione reductase and glutathione peroxidase activity of human erythrocytes. Braz J Med Biol Res., 24(5): 449-54.

Muller, F. L., Song, W., Jang, Y. C., et al. (2007). Denervation-inducedskeletal muscle atrophy is associated with increasedmitochondrial ROS production. Am J Physiol Regul Integr CompPhysiol, 293: R1159-68.

Musumeci, G., Imbesi, R., Szychlinska, M.A. and Castrogiovanni, P. (2015). Apoptosis and Skeletal Muscle in Aging. Open J. Apoptosis, 4: 41-46.

Nabben, M., Shabalina, I. G., MoonenKornips, E., et al. (2011). Uncoupled respiration, ROS production, acute lipotoxicity and oxidative damage in isolated skeletal muscle mitochondria fromUCP3-ablated mice. Biochim Biophys Acta, 1807:1095-105.

Natasa Miljkovic, Jae-Young Lim, Iva Miljkovic, Walter R. Frontera, (2015). Aging of Skeletal Muscle Fibers. Ann Rehabil Med., 39(2):155-162.

Reinking, Ben E. (1996). The effect of aging on skeletal muscle regeneration. Presidential Scholars Theses, 10:1990 2006.

Sakakima, H., Yoshida, Y., Suzuki, S. and Morimoto, N. (2004). The Effects of Aging and Treadmill Running on Soleus and Gastrocnemius Muscle Morphology in the Senescence-Accelerated Mouse (SAMP1). J Gerontol A Biol Sci Med Sci., 59(10):1015-21.

Salo, D. C., Pacifini, R. E. and Davies, K.J. (1988). Superoxide dismutase is preferentially degraded by a proteolytic stem from red blood cells following oxidative modification by hydrogen peroxide. Free Rad Biol. Med., 5: 335-9.

Sandri, M. (2008). Signaling in muscle atrophy and hypertrophy Physiology. (Bethesda), 23 pp. 160-170.

Santilli, V., Bernetti, A., Mangone, M. and Paoloni, M. (2014). Clinical definition of sarcopenia. Clin. Cases Miner. Bone Metab., 11: 177-180.

Scime, A., Caron, A. Z. and Grenier, G. (2009). Advances in myogenic cell transplantation and skeletal muscle tissue engineering. Front. Biosci., 14: 30123023.

Sheard, P. W. and Anderson, R. D. (2012). Age-related loss of muscle fibres is highly variable amongst mouse skeletal muscles. Biogerontology, 13:157-167.

Suresh D.R., Sendil, K., Annam V. and Hamasaveena (2010). Age related changes in malondialdehyde: total antioxidant capacity ratio- a novel marker of oxidative stress. Int. J. Pharm. Bio. Sci., 1(2): 1-6.

Tsochatzis, E.A., Bosch, J. and Burroughs, A.K. (2014). Liver cirrhosis. Lancet, 383: 1749-1761.

Xu, J. B., Yuan, X. F., and Lang, P. Z. (1997): Determination of catalase activity and catalase inhibition by ultraviolet spectrophotometry. Chinese Environ. Chem., 16: 73-76.

Yoshioka, T., Kawada, K., Shimada, T. and Mori, M. (1979): Lipid peroxidation in maternal and cord blood and protective mechanism against activated-oxygen toxicity in the blood. Am J. Obstet Gynecol., 135(3):372-376. 